\title{
ABA Business Law Section, on behalf of its committees on LLCs and Nonprofit Organizations, opposes legislation for low profit limited liability companies (L3Cs)
}

Daniel S. Kleinberger

Mitchell Hamline School of Law, daniel.kleinberger@mitchellhamline.edu

Publication Information

Professor Kleinberger posts this document as the chair of the L3C Review Subcommittee of the Committee on Limited Liability Companies, Partnerships and Unincorporated Entities. The letter and attachment were principally drafted by that Subcommittee and sent to Minnesota Representative Steve Simon on April 19, 2012.

\section{Repository Citation}

Kleinberger, Daniel S., "ABA Business Law Section, on behalf of its committees on LLCs and Nonprofit Organizations, opposes legislation for low profit limited liability companies (L3Cs)" (2012). Faculty Scholarship. Paper 228.

http://open.mitchellhamline.edu/facsch/228 


\title{
ABA Business Law Section, on behalf of its committees on LLCs and Nonprofit Organizations, opposes legislation for low profit limited liability companies (L3Cs)
}

\begin{abstract}
This document comprises a letter and attachment "submitted by the ABA Business Law Section on behalf of its Committee on Limited Liability Companies, Partnerships, and Unincorporated Entities and its Committee on Nonprofit Organizations ... and states our views on ... a bill 'relating to limited liability companies [and] providing for the creation and operation of low-profit limited liability companies." The letter and attachment "have not been approved by the House of Delegates or the Board of Governors of the American Bar Association and should not be construed as representing the policy of the ABA."
\end{abstract}

Supported by detailed analysis of both tax and LLC law, the letter makes the following major points:

- The $\mathrm{L} 3 \mathrm{C}$ is no better than any other business form for receiving program related investments from private foundations. L3C legislation implies otherwise and we believe is therefore misleading.

- Using a program related investment as part of the type of tranched financing promoted by L3C advocates portends serious risk of improper "private benefit" - i.e., using charitable assets to the benefit of private interests such as for-profit investors. "Private benefit" transactions are improper for a private foundation and imperil a foundation's tax-exempt status. A private foundation cannot remain qualified as a tax-exempt charitable entity if the foundation has transgressed the private benefit doctrine.

- In addition:

- enacting L3C legislation inadvertently but dangerously signals that state law can streamline and simplify compliance with federal tax law requirements and that program related investments can be accomplished simply, quickly, and almost "off the rack;"

- it is inappropriate and unnecessary to use state entity law to provide a new and potentially misleading "brand" to mark private business ventures as socially beneficial;

- the L3C legislation contains a technical flaw that renders the legislation self-defeating in most instances; and

- current LLC law already permits the type of ventures contemplated by the L3C legislation.

\section{Keywords}

low profit limited liability company, L3C, hybrid, social justice, benefit corporation, business, ABA, American Bar Association, Business Law Section, LLC, limited liability company, tranched, program related investment, PRI, social benefit, jeopardizing investment, moral capitalism, private foundation

\section{Disciplines}

Business Organizations Law | Organizations Law 


\begin{tabular}{|c|c|}
\hline \\
\hline $\begin{array}{r}\text { ASSOCIATION YEAR 2011-2012 } \\
\text { CHAIR } \\
\text { Linda Rusch } \\
29112^{\text {nd }} \text { Avenue, Unit } 1019 \\
\text { Seattle, WA 98121-3055 }\end{array}$ & \\
\hline $\begin{array}{r}\text { CHAIR-日eCT } \\
\text { Martin E. LLbecker } \\
700 \text { 133th Street NW, Suite } 600 \\
\text { Washington, DC } 20005\end{array}$ & \\
\hline $\begin{array}{r}\text { VICE CHAIR } \\
\text { Dixie J Jnsson } \\
80117^{\text {th }} \text { Street NW }\end{array}$ & April 19, 2012 \\
\hline Washington, DC 20006 & The Honorable Steve Simon \\
\hline $\begin{array}{l}\text { SECRETARY } \\
\text { Paul "Chip" Lazard Lion, III } \\
755 \text { Page Mill Road }\end{array}$ & Assistant Minority Leader \\
\hline Palo Alto, CA 94304 & Minnesota House of Representatives \\
\hline $\begin{array}{l}\text { BUDGETOFACER } \\
\text { Renie Yoshida G Grohl } \\
8300 \text { Fox Hound Run, NE }\end{array}$ & 279 State Office Building \\
\hline Warren, $\mathrm{OH} 44484$ & 100 Rev. Dr. Martin Luther King Jr. Blvd \\
\hline $\begin{array}{r}\text { CONIENTOFACER } \\
\text { J onathan C. Lipson } \\
975 \text { Bascom Mall } \\
\text { Madison, WI } 53706\end{array}$ & Minneapolis, MN 55155-1298 \\
\hline $\begin{array}{r}\text { IMMEDIATE PASTCHAIR } \\
\text { Lynne B Barr } \\
\text { Exchange Place } \\
5 \text { State Street } \\
\text { Boston, MA 02109 }\end{array}$ & Re: House File No. 2702 - Low Profit Limited Liability Companies (L3C) \\
\hline $\begin{array}{l}\text { SEC TON DEEGATES TO } \\
\text { BA HOUSE OF DEIEGATES }\end{array}$ & ar Represent \\
\hline
\end{tabular}
Lynne B. Barr
Boston, MA

Mary Beth Clary Naples, FL

Maury B. Posc over St. Louis, MO

Steven $O$. Weise Los Angeles, CA COUNCIL

Margaret M. Foran Newark, NJ

Lawrence A. Hamemesh
Wilmington, DE Myles V. Lynk Tempe, AZ

Christopher J, Rockers Kansas City, MO Jolene A. Yee Modesto, CA

Doneene Keemer Damon Wilmington, DE J ean K. FitzSimon Phila delphia, PA

Lawrence A. Goldman Newark, NJ

J oell. G reenberg
New York, NY

Donald C. Lampe Greensboro, NC

Warren E. Agin Boston, MA

Patrick T. Clendenen Boston, MA

Frances Gauthier Geneva, Switzerland

Samantha Hom

ter J. Walsh, J $r$.

Wilmington, DE

Michael St. Patrick Baxter Washington, DC Carol Hansell
Toronto, ON Ben F. Tennille Winston Salem, NC Vicki O. Tucker Richmond, VA

JamesJ. Wheaton
Virginia Beach, VA BOARD OF GOVERNORS UAISON Barbara Mendel Mayden Nashville, $\mathrm{TN}$ SECTION DIRECTOR
SUsan Daly Tobias Chicago, IL (312) 988-6244 This letter is submitted by the ABA Business Law Section on behalf of its Committee on Limited Liability Companies, Partnerships, and Unincorporated Entities and its Committee on Nonprofit Organizations ("the Committees”) and states our views on House File No. 2702, a bill "relating to limited liability companies [and] providing for the creation and operation of low-profit limited liability companies." ("the L3C legislation" or "the legislation"). Attachment A explains our views in detail. This letter and Attachment A have not been approved by the House of Delegates or the Board of Governors of the American Bar Association and should not be construed as representing the policy of the ABA.

We recognize that many people of good will are seeking methods to increase the flow of capital to socially beneficial business enterprises. As part of that effort, the proponents of L3Cs argue that the L3C provides a new vehicle to increase that capital flow:

- by facilitating the leveraging of federal tax benefits,

- through obtaining funds in the form of tax-favored, program related investments ("PRIs"),

- from heavily regulated charitable private foundations whose assets are obtained and maintained under the aegis of federal tax benefits.

We have carefully studied the L3C legislation and relevant federal tax law and have concluded that, under current federal tax law:

The L3C is no better than any other business form for receiving program related investments from private foundations. L3C legislation implies otherwise and we believe is therefore misleading. 


\section{Using a program related investment as part of the type of tranched financing promoted by L3C advocates portends serious risk of improper "private benefit" - i.e., using charitable assets to the benefit of private interests such as for-profit investors. "Private benefit" transactions are improper for a private foundation and imperil a foundation's tax-exempt status. A private foundation cannot remain qualified as a tax-exempt charitable entity if the foundation has transgressed the private benefit doctrine.}

L3C legislation is completely ineffective in providing advantages over any other legal form of business organization in obtaining PRIs, and is, moreover, at odds with precisely those aspects of the federal tax law which the L3C legislation seeks to invoke.

L3C advocates heavily promote a particular type of "tranched investment" structure as a core benefit of the L3Cs, ${ }^{1}$ but this structure is dangerous for any private foundation. In the tranched investment structure promoted by L3C advocates, a private foundation makes a high-risk/low-return investment, which enables the recipient organization to offer attractive terms to one or more other "tranches" of for-profit investors. Although the recipient organization may itself have socially beneficial purposes, by definition one of its purposes is to provide profit for the for-profit investors (including above market rates for the top "tranche" of investors).

Thus, the tranched investment structure commingles assets from private foundations with capital investments from private profit seekers and inevitably uses charitable assets to confer "private benefit" on the for-profit investors in the recipient organization. If, qualitatively and quantitatively, those benefits are not merely incidental to furthering exempt (i.e., charitable) purposes, the risk to the investing private foundation is extreme i.e., loss of its tax exempt status.

The same concerns would exist if an ordinary limited liability company ("LLC”) or a forprofit corporation were to deploy private foundation funds in a tranched investment structure. The special danger of L3C legislation is that enactment gives a misleading state-government imprimatur to a structure that: (i) does nothing distinctively beneficial to accomplish its purported goals; and (ii) to the contrary, may mislead unsophisticated people of good will into significant federal tax problems. The tranched investment structure is apt to be promoted as having been approved by any state legislature that adopts L3C legislation.

In addition, we note that: (i) enacting L3C legislation inadvertently but dangerously signals that state law can streamline and simplify compliance with federal tax law

\footnotetext{
${ }^{1}$ See, e.g., Americans for Community Development, “What is an L3C?” at http://www.americansforcommunitydevelopment.org/downloads/What\%20is\%20the\%20L3C101010.pdf (last visited June 27, 2011) (“The L3C facilitates PRI investment without the need for IRS private letter rulings. It also facilitates tranched investing with the PRI usually taking first risk position thereby taking much of the risk out of the venture for other investors in lower tranches. The rest of the investment levels or tranches become more attractive to commercial investment by improving the credit rating and thereby lowering the cost of capital. It is particularly favorable to equity investment. Because the foundations take the highest risk at little or no return, it essentially turns the venture capital model on its head and gives many social enterprises a low enough cost of capital that they are able to be self sustainable.”)
} 
requirements and that program related investments can be accomplished simply, quickly, and almost "off the rack;" (ii) it is inappropriate and unnecessary to use state entity law to provide a new and potentially misleading "brand" to mark private business ventures as socially beneficial; (iii) the L3C legislation contains a technical flaw that renders the legislation self defeating in most instances; and (iv) current LLC law already permits the type of ventures contemplated by the L3C legislation.

For all these reasons, we respectfully urge you to oppose House File No. 2702.

On behalf of the Section and our Committees, thank you for considering our views on these important issues. If we can provide any further information (including testimony), please contact Scott Ludwig, Chair of our Committee on Limited Liability Companies, Partnerships and Unincorporated Entities at sludwig@babc.com or (256) 517-5149 or Michael Malamut, Chair of our Committee on Nonprofit Organizations at michael@michaelmalamut.com or (781)329-9096.

Respectfully submitted,

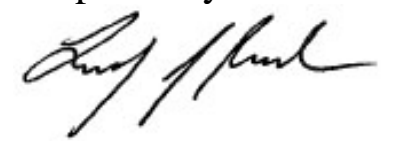

Linda J. Rusch

Chair, ABA Business Law Section

cc: $\quad$ Scott Ludwig, Esq.

Michael Malamut, Esq.

Thomas M. Susman, Director, ABA Governmental Affairs Office

R. Larson Frisby, Associate Director, ABA Governmental Affairs Office

Alpha M. Brady, Director, ABA Policy Administration Division 


\section{Appendix A \\ In re: Minnesota House File No. 2702}

\section{Outline of Contents}

I. General Background - LLCs and L3Cs

II. Tax-Based Strictures on Private Foundations - In General

III. The Prohibition of Private Benefit
A. In General
B. Private Benefit and the L3C
C. Private Benefit, the L3C, and Tranched Investing

IV. Jeopardizing Investments
A. In General
B. Jeopardizing Investments and the L3C
C. Jeopardizing Investments, the L3C, and Tranched Investing

V. III. Program Related Investments
A. In General
B. Expenditure Responsibility
C. Potential Fiduciary Duties of Private Foundation to Recipient Organization and Organization's Other Investors
D. General Effect of PRI Requirements, Expenditure Responsibility, Potential Fiduciary Duties, and the Risk of Private Benefit
E. PRIs and L3Cs
F. PRIs, L3Cs, and Tranched Investment

VI. Federal Tax Requirements and the L3C - Summary

VII. Defects in the L3C Legislation
A. The Misleading Implications of L3C Legislation
1. In General
2. L3Cs and Tranched Investment
B. State Entity Law Not Appropriate Method to Create a "Brand" to Identify Socially Beneficial Ventures
C. The Technical Error in the L3C Legislation
D. No Need for an L3C Subcategory

VIII. Conclusions 


\section{General Background - LLCs and L3Cs}

Over the past 25 years, the LLC has become the dominant form of legal entity for business organizations whose ownership interests are not publicly traded. For example, last year in Minnesota, 5965 new corporations were incorporated, while 24,923 new LLCs were organized. $^{2}$

L3C legislation seeks to establish a special form of LLC, known as the low profit limited liability company (“L3C”). Typical L3C legislation provides that an LLC designated as an L3C must: (1) significantly further a charitable purpose; (2) have no significant purpose of producing income or the appreciation of property; and (3) not engage in lobbying. ${ }^{3}$

L3C advocates assert that the L3C will further socially constructive goals by facilitating cooperation between non-profit and for-profit enterprises - in particular by encouraging private foundations to invest charitable funds in L3Cs which will leverage those funds to attract for-profit capital investments or otherwise provide financial support to a business enterprise with for profit owners. The fulcrum of the L3C concept is a component of federal tax law - the program related investment (PRI).

The leverage advocated for the L3C is a particular type of tranched investing - an arrangement in which a private foundation makes a high-risk/low-return investment, which enables the recipient organization to offer attractive terms or otherwise provide investment enhancement to one or more other "tranches" of for-profit investors. L3C advocates assert that this combination of capital enables the socially beneficial enterprise to pursue both self-sufficiency and the enterprise's social goals.

\section{Tax-Based Strictures on Private Foundations - In General}

Private foundations enjoy tax-exempt status. ${ }^{4}$ In return, they face comprehensive and complex tax requirements designed to: (i) preclude diversion of charitable assets to noncharitable purposes or private persons; ${ }^{5}$ (ii) deter investment of charitable assets that might jeopardize a foundation's charitable purpose; ${ }^{6}$ (iii) require each foundation annually to make a specified minimum distribution in furtherance of the foundation's charitable purpose; ${ }^{7}$ and (iv) permit the required minimum amount to be met, in part or in

\footnotetext{
${ }^{2}$ Source: spreadsheet provided April 2, 2012 by the Office of the Secretary of State of Minnesota.inser

${ }^{3}$ L3C statutes also typically provide that the production of significant income or appreciation is not itself conclusive of a purpose to do so. In other words, if the LLC makes a great profit, disqualification under the state definition does not result automatically.

${ }^{4}$ IRC $\$ 501(a)$.

${ }^{5}$ See the authorities cited in note 8.

${ }^{6}$ Treas. Reg § 53.4944-1.

${ }^{7}$ IRC $\$ 4942$.
} 
whole, through tightly controlled and carefully considered investments in for-profit enterprises when the investment is designed to further the investing foundation's charitable purpose. ${ }^{8}$

For the purposes of making a tax-based analysis of L3Cs and tranched investing, the following concepts are the most important: (i) private benefit; (ii) jeopardizing investments; (iii) PRIs; and (iv) expenditure responsibility.

With regard to each of these concepts, the L3C provides no special benefit whatsoever. With regard to several of these concepts, tranched investing can be dangerous or fatal to a private foundation's tax exempt status. In all events, PRIs always require careful of planning and design plan specially tailored to the charitable purpose of the investing foundation.

\section{The Prohibition of Private Benefit}

\section{A. In General}

A prohibition on non-incidental "private benefit" overarches every aspect of a private foundation’s operations and programs.

After extensive hearings in 1969, Congress singled out "private foundations" from the tax-exempt population and subjected them to a series of intricate restrictions of unprecedented severity, which are buttressed by extensive reporting requirements.... [T] he underlying policy apparently is that additional regulation of foundations is required to ensure that their income and assets are not used inconsistently with the basic premise of the charitable deductions and exemption--that the deducted and exempted amounts should be used for public rather than private benefit. ${ }^{9}$

Private benefit is prohibited unless merely incidental to furthering the foundation's exempt purposes. ${ }^{10}$ A private foundation that breaks the rule against private benefit risks a draconian penalty - loss of the foundation's tax-exempt status. ${ }^{11}$

${ }^{8} \S 53.4942(a)-3(a)(2)(i)$.

${ }^{9}$ Boris I. Bittker and Lawrence Lokken, Federal Taxation of Income, Estates and Gifts, § 101.1 (available at 1997 WL 440016 (W.G.\&.L.) (current through 2011

${ }^{10}$ Better Business Bureau v. United States, 326 US 279, 283 (1945) (“'[T]he presence of a single non[exempt] purpose, if substantial in nature, will destroy the exemption regardless of the number or importance of truly [exempt] purposes.'). Universal Church of Jesus Christ, Inc. v. C.I.R. T.C. Memo. 1988-65, 1988 WL 12612 (1988) (“The regulations under section 501(c)(3) not only require an organization to be operated for one or more exempt purposes, but require that organization to be 'operated exclusively' for such purposes. Sec. 1.501(c)(3)-1(c)(1), Income Tax Regs. However, 'An organization which engages in nonexempt activities can obtain and maintain exempt status so long as such activities are only incidental and less than substantial.' Church in Boston v. Commissioner, 71 T.C. 102, 107 (1978).”). See also United Cancer Council, Inc. v. Comm'r, 165 F3d 1173, 1179-1180 (1999) (Posner, J.) (“The usual 'private benefit' case is one in 


\section{B. Private Benefit and the L3C}

Any comingling of for-profit goals and charitable assets inevitably raises the specter of improper private benefit. Despite claims to the contrary, the L3C structure contains no "magic bullet" for this problem. To the contrary, nothing in the L3C structure prevents private benefit. An L3C is a low profit limited liability company, not a "no profit" limited liability company. Moreover, the L3C legislation does not prevent an L3C from shucking its L3C status and becoming a "profit above all” LLC.

An L3C operating agreement can be structured to avoid that transformation, but the operating agreement of an ordinary LLC can do likewise - even to the extent of granting a non-member a veto right over any change in the socially beneficial mission of the LLC. ${ }^{12}$

In any event, the mixing of for-profit (even low profit) motives with charitable purposes requires nuanced thinking, thoughtful planning, and expert professional advice. When private benefit is possible, the stakes are very high. A private foundation that transgresses the prohibition on private benefit risks its very existence as an exempt organization.

which the charity has dual public and private goals ... and ... the board of a charity has a duty of care, just like the board of an ordinary business corporation and a violation of that duty which involved the dissipation of the charity's assets might support a finding that the charity was conferring a private benefit, even if the contracting party did not control, or exercise undue influence over, the charity.”). See also Boris I. Bittker and Lawrence Lokken, Federal Taxation of Income, Estates and Gifts, 9100.4 INUREMENT OF EARNINGS TO PRIVATE INDIVIDUALS, 1997 WL 440011 (footnotes omitted) ("The IRS has, in recent years, given increased attention to compensation arrangements between exempt hospitals and physicians. For example, in 1992, it noted that some hospitals claiming exemption under § 501(c)(3) 'have formed joint ventures with members of their medical staff and sold to the joint venture the gross or net revenue stream derived from the operation of an existing hospital department or service for a defined period of time.' Such an arrangement jeopardizes the exemption, according to the IRS, because it 'causes the hospital's net earnings to inure to the benefit of private individuals (the physician investors),' the 'private benefit flowing from the transaction 'cannot be considered incidental to the public benefits received,' and the arrangement may violate federal law.”).

${ }^{11}$ IRC §§ 4941-4945.

${ }^{12}$ See e.g. Revised Uniform Limited Liability Company Act (“Re-ULLCA”), § 112(a) (“An operating agreement may specify that its amendment requires the approval of a person that is not a party to the operating agreement or the satisfaction of a condition. An amendment is ineffective if its adoption does not include the required approval or satisfy the specified condition.”); Del. Code Ann. tit. 6, § 18-101(7) ("A limited liability company agreement may provide rights to any person, including a person who is not a party to the limited liability company agreement, to the extent set forth therein.”). Neither Re-ULLCA nor the Delaware LLC Act require an ordinary LLC to have a for-profit purpose. Re-ULLCA, \$104(b) ("A limited liability company may have any lawful purpose, regardless of whether for profit.”); Del. Code Ann., tit. 6, § 18-106(a) (providing that “[a] limited liability company may carry on any lawful business, purpose or activity, whether or not for profit”). Even under an LLC statute that requires a business purpose, that requirement does not prevent LLC owners from agreeing to mix social benefits with their business or from agreeing to operate their business in a socially beneficial way. 


\section{Thus, the notion that the L3C is superior to the LLC in dealing with the issue of private benefit is unfounded and misleading. Whatever type of organization is used, there is no quick fix and no simple way out. "Off the rack" solutions are recipes for disaster.}

\section{Private Benefit, the L3C, and Tranched Investing}

As extolled by L3C proponents, the tranched investment mechanism is a multiple-tiered investment strategy under which the foundation makes an investment in an L3C with the highest risk and lowest return. This capital permits an L3C to leverage the foundation's investment to attract other investors for other investment tiers at a lower risk and higher return. $^{13}$

${ }^{13}$ E.g., The Florida Senate Committee on Commerce, An Overview Of Low-Profit Limited Liability Companies (L3Cs), Issue Brief 2011-210 (Oct. 2010), http://www.flsenate.gov/Committees/InterimReports/2011/2011-210cm.pdf ("Ideally, the structure of an L3C allows for three tranches of investment; the equity tranche, the mezzanine tranche, and the senior tranche. The first level of investment, the equity tranche or junior tranche, consists of investors that seek little or no returns on their contribution. For L3Cs, equity tranche investors are likely to be private foundations making program related investments (PRIs) as they are prohibited by federal regulations from contemplating a financial return as their motive for investment. Once this initial equity investment is made in the L3C, it absorbs most of the financial investment risk, making the L3C a more attractive investment for the mezzanine tranche of investors.... Senior tranche, or third tier, investments are provided by investors that seek market-rate returns. These types of investors are likely to make investments with guaranteed returns or returns that are keyed to the L3C's profits, which is possible given that the equity tranche and mezzanine tranche of investments take on most of the financial risk.”); S3011-2011: Relates to establishing the L3C act regarding low-profit limited liability companies, http://m.nysenate.gov/legislation/bill/S3011-2011 ("It is also envisioned to facilitate tranched investing by foundations, with a PRI taking the first risk position and thereby taking much of the risk out of the venture for other investors in lower tranches."). See also Antony Page \& Robert A. Katz, "Is Social Enterprise the New Corporate Social Responsibility?” 34 SEATTLE U. L. REV. 1351, 1363-64 (2011) ("Proponents of the L3C form envision that its controllers can leverage these program-related investments with private capital to achieve its social aims, which would also serve the investing foundation's purposes. On this model, investments in L3Cs would be structured in tranches: program-related investments would ideally take the riskiest position in the capital structure and receive no or lower returns, thereby lowering risk and increasing returns for other equity investors. The top tranche might be at the risk-adjusted market rate of return. There might also be a "mezzanine" tranche, designed for investors willing to accept a lower return because of their contribution to social welfare.”); David Shevlin \& Jennifer Maimone-Medwick, "Low-Profit Limited Liability Companies ('L3CS'): A Fact Sheet," SS019 ALI-ABA 179, 181 (2010) ("The ability to tranche the stake of the various investors allows for uneven allocation of risk and reward among investors could open up additional streams of capital, both from private foundations ... and from individuals. For example, a private foundation could make an investment in a junior tranche, absorbing excess risk and receiving below market returns, and a more senior tranche could be offered to attract additional capital from non-charitable investors that could generate a market rate of return, while investing in projects that provide tangible social benefits. The market rate of return can be offered due to the lower rate of return obligations on the private foundation's investment.”); Elizabeth Schmidt, "Vermont's Social Hybrid Pioneers: Early Observations and Questions To Ponder,” 35 VT. L. REV. 163, 169 (2010) ("The L3C creators reasoned that a private foundation would make the initial investment in an L3C through a PRI. That investment would be the investment with the highest risk and the lowest rate of return. It would provide the initial equity capital to the L3C, which would then give the L3C sufficient capital to attract investors who would otherwise have found the investment too risky. Such investors would then become a part of a separate membership class (or tranche) in the L3C, a class that could expect a higher rate of return than the foundation did. This 
There is absolutely nothing special about an L3C to make possible a tranched investment arrangement. Indeed, the federal tax ruling closest in concept (although not involving tranched investing) was a private letter ruling involving a private foundation investment in an ordinary LLC. ${ }^{14}$

As promoted by L3C advocates, tranched investing purposefully uses foundation funds to subsidize (and thereby attract) private, profit-seeking investors. The principal goal may be laudable but the means - using charitable funds to enrich "top tranche" investors - portends serious risk of private benefit. ${ }^{15}$

class might become a middle tranche of investors, those who still accept a below market rate of return in order to encourage a social return. Ultimately, a class of investors who expect a market rate of return could emerge. Thus, the PRI would not only provide capital; it would also leverage additional investment."); Americans for Community Development, "The Concept of the L3C,"

http://www.americansforcommunitydevelopment.org/concept.php, last visited 7/24/11 ("The L3C facilitates tranching or layering. The keys to an L3C's operation is its use of low-cost foundation capital in a high risk tranche of its structure and its ability to allocate risk and reward unevenly over a number of investors, thus ensuring some a very safe investment with market return. As is appropriate under the PRI structure, foundations would normally be expected to assume the highest risk at very low return, making the rest of the investment far more secure.”). The same strategy could be pursued with an ordinary LLC or even a for-profit corporation. However, the strategy is promoted in relationship to L3Cs.

${ }^{14}$ I.R.S. Priv. Ltr. Rul. 200610020 (Mar. 10, 2006).

${ }^{15}$ Compare this type of private benefit with the situation described in I.R.S. Priv. Ltr. Rul. 200610020 (Mar. 10, 2006). The ruling letter described an arrangement in which: (i) the private foundation and the other LLCs members shared risk and return equally; and (ii) the other members were investing not only to lend their personal, sports-based prestige the project's goal of "investing in businesses in low-income communities owned or controlled by members of a minority or other disadvantaged group" but also to receive mandatory training in how to use their wealth through "angel investing and entrepreneurship." See also the authorities cited in note 8 and Boris I. Bittker and Lawrence Lokken, Federal Taxation of Income, Estates and Gifts, 9100.4 (Inurement of Earnings of Private Individuals), 1997 WL 440011. In 9100.4 of their treatise, Bittker and Lokken discuss the private benefit resulting from a different arrangement for intertwining non-profit and for-profit activity: "The IRS has, in recent years, given increased attention to compensation arrangements between exempt hospitals and physicians. For example, in 1992, it noted that some hospitals claiming exemption under § 501(c)(3) 'have formed joint ventures with members of their medical staff and sold to the joint venture the gross or net revenue stream derived from the operation of an existing hospital department or service for a defined period of time.' Such an arrangement jeopardizes the exemption, according to the IRS, because it 'causes the hospital's net earnings to inure to the benefit of private individuals (the physician investors),' the "private benefit flowing from the transaction 'cannot be considered incidental to the public benefits received,' and the arrangement may violate federal law.'”) (footnotes omitted). 


\section{Jeopardizing Investments}

\section{A. In General}

Tax law uses the concept of "jeopardizing investments" to channel private foundations and their managers toward careful, mission-oriented investments. ${ }^{16}$ "If a private foundation invests any amount in such a manner as to jeopardize the carrying out of any of its exempt purposes," both the foundation and its managers face substantial excise taxes. ${ }^{17}$

Program related investments (PRIs), discussed below, are exempt from the jeopardizing investment analysis. ${ }^{18}$ For all other investments by private foundations, the following standard applies:

[A]n investment shall be considered to jeopardize the carrying out of the exempt purposes of a private foundation if it is determined that the foundation managers, in making such investment, have failed to exercise ordinary business care and prudence, under the facts and circumstances prevailing at the time of making the investment, in providing for the longand short-term financial needs of the foundation to carry out its exempt purposes. $^{19}$

The rule's purpose is to safeguard each foundation's financial ability to purpose its charitable purpose, and the focus is largely financial:

In the exercise of the requisite standard of care and prudence the foundation managers may take into account the expected return (including both income and appreciation of capital), the risks of rising and falling price levels, and the need for diversification within the investment portfolio (for example, with respect to type of security, type of industry, maturity of company, degree of risk and potential for return). The determination whether the investment of a particular amount jeopardizes the carrying out of the exempt purposes of a foundation shall be made on an investment by investment basis, in each case taking into account the foundation's portfolio as a whole. ${ }^{20}$

\footnotetext{
${ }^{16}$ IRC § 4944(a)(1); Treas. Reg. \$§ 53.4944-1 and 53.4944-2

${ }^{17}$ IRC § 4944(a) and (b).

${ }^{18}$ IRC § 4944(c).

19 Treas. Reg § 53.4944-1(a)(2). Even a mission oriented investment might be jeopardizing if the risks were high and the investment comprised an imprudently large proportion of the foundation's assets.

${ }^{20} I d$.
} 


\section{B. Jeopardizing Investments and the L3C}

A private foundation's investment in a L3C is not automatically a jeopardizing investment. As explained below, a valid PRI is not a jeopardizing investment, and "[n]o category of investments shall be treated as a per se violation of section 4944 [the jeopardizing investment rule]."21

However, in general, investment in an L3C poses greater risk than investment in a for-profit enterprise and portends lower returns. Almost by definition, L3Cs intentionally seek opportunities unattractive to investors driven "merely" by the calculus of profit and loss. ${ }^{22}$ Thus, it could hardly be the "exercise [of] ordinary business care and prudence" for a private foundation to commit a substantial portion of its assets to an $\mathrm{L} 3 \mathrm{C}$.

Moreover, state legislation can do nothing to affect the "investment by investment" determination required of a private foundation and its managers. "[No] ... State law [may] exempt or relieve any person from any obligation, duty, responsibility, or other standard of conduct provided in section 4944 and the regulations thereunder." 23

\section{Jeopardizing Investments, the L3C, and Tranched Investing}

Tranched investing, in the form advocated by L3C proponents, can significantly increase a private foundation's risk of making a jeopardizing investment, especially for foundations with limited assets. In that particular tranched investing structure, the private foundation is a high risk/low return investor precisely the opposite of what a careful investor typically seeks.

${ }^{21} I d$.

${ }^{22}$ Put another way: if careful investors consider a particular venture to be a worthwhile investment, the market will fund the venture. There will be no need for a nonprofit or "low profits" enterprise to step in.

${ }^{23}$ Treas. Reg §53.4944-1(a)(2)(i). 


\section{Program Related Investments}

\section{A. In General}

Under IRC, \$ 4944(c), "investments, the primary purpose of which is to accomplish one or more of the [charitable] purposes described in section 170(c)(2)(B), and no significant purpose of which is the production of income or the appreciation of property, shall not be considered as investments which jeopardize the carrying out of exempt purposes." In addition, a PRI counts toward a foundation's annual distribution requirement. Thus for a private foundation considering an investment in a for-profit entity, PRI status is invaluable. $^{24}$

The PRI regulations are specific in defining a PRI:

A program-related investment is an investment which possesses the following characteristics:

(i) The primary purpose of the investment is to accomplish one or more of the purposes described in section 170(c)(2)(B) [charitable purposes];

(ii) No significant purpose of the investment is the production of income or the appreciation of property; and

(iii) No purpose of the investment is to accomplish one or more of the purposes described in section170(c)(2)(D) [influence legislation/elections]. ${ }^{25}$

According to the regulations, the first PRI requirement is specific to the mission of the particular foundation seeking to make a PRI:

An investment shall be considered as made primarily to accomplish one or more of the purposes described in section 170(c)(2)(B) if it significantly furthers the accomplishment of the private foundation's exempt activities and if the investment would not have been made but for such relationship between the investment and the accomplishment of the foundation's exempt activities. $^{26}$

The second PRI requirement ("no significant purpose [to produce] income or ... appreciation”0 authorizes high risk/low return investments in the proper circumstances. However, PRI status does not exempt a private foundation from the strictures on private benefit and the severe risks to any private foundation that runs afoul of those strictures.

\footnotetext{
${ }^{24}$ A PRI is also a "qualifying distribution” as provided in Treas. Reg. § 53.4942(a)-3(a)(2)(i) and therefore counts towards a private corporation’s annual required distribution amount under IRC $\$ 4942$.

${ }^{25}$ Treas. Reg. § 53.4944-3(a)(1).

${ }^{26}$ Id. at $\S 53.4944-3(\mathrm{a})(2)(\mathrm{i})$.
} 
In addition, PRI status does not override the requirement that any program related investment be mission specific. The relevant mission is that of the private foundation. Thus, PRI analysis must always focus on the specific charitable purpose of the private foundation. No state law designation can make a recipient organization generically qualified to receive PRIs or even categorically superior to other state law entity types.

\section{B. Expenditure Responsibility}

In addition to the requirements just described, a private foundation that makes a PRI must exercise "expenditure responsibility" so as to assure the recipient organization will properly use the invested charitable assets. ${ }^{27}$ "Expenditure responsibility" requires the foundation "to exert all reasonable efforts and to establish adequate procedures - (1) to see that the [PRI] is spent solely for the purpose for which made, (2) to obtain full and complete reports from the [recipient organization] on how the funds are spent, and (3) to make full and detailed reports with respect to such expenditures to the Secretary [of the Treasury]."28 Failure to exercise "expenditure responsibility" subjects the foundation and its managers to substantial excise taxes. ${ }^{29}$

\section{Potential Fiduciary Duties of Private Foundation to Recipient Organization and Organization's Other Investors}

When a private foundation invests in a for-profit organization (even a low profit version), the foundation may become a part owner of that organization. ${ }^{30}$ If so, the foundation must consider what fiduciary or other duties it may have under the state entity law applicable to the recipient organization. In general, fiduciary duty tends to follow power over other people's investment, and under federal tax law a foundation making a PRI must have in place powerful constraints on the activities of the recipient organization. By complying with federal tax law requirements, a foundation and its managers might find themselves exposed to state law claims for breach of fiduciary duty. ${ }^{31}$ This problem is not insurmountable, but - like so many matters that arise from co-mingling charitable assets

${ }^{27}$ IRC § 4945(d)(4)(B). The Code applies this requirement to "grants" but the regulations define "grants" to include "program related investments.” Treas.Reg. \$53.4945-4(a)(2) (stating that "[f]or purposes of section 4945, the term 'grants' shall include ... 'program related investments'”).

${ }^{28}$ IRC § 4945(h).

${ }^{29}$ IRC § 4945(a)-(b). The Code defines “foundation manager” to mean "with respect to any private foundation-(1) an officer, director, or trustee of a foundation (or an individual having powers or responsibilities similar to those of officers, directors, or trustees of the foundation), and (2) with respect to any act (or failure to act), the employees of the foundation having authority or responsibility with respect to such act (or failure to act).” IRC $§ 4946$ (b).

${ }^{30}$ A foundation might also make a PRI in the form of a loan at a below-market interest rate. See e.g. Treas. Reg. § 53.4944-3(b)(2) (example).

${ }^{31}$ For example, it requires considerable care to establish the proper balance between duties owed for-profit investors and need to avoid improper private benefit. 
with for-profit purposes - the problem requires sophisticated rather than simplistic analysis.

\section{General Effect of PRI Requirements, Expenditure Responsibility, Potential Fiduciary Duties, and the Risk of Private Benefit}

A private foundation contemplating a PRI must take into account the PRI requirements and expenditure responsibility, take note of potential fiduciary duties under the relevant state entity law, and pay very careful attention to any risk of private benefit. This complex combination of requirements means that whenever a foundation seriously contemplates a PRI, the foundation must make a careful, fact-specific assessment of: (i) the connection between the foundation's charitable purpose and the purposes of the proposed recipient; (ii) the structures in place in the recipient organization to assure the recipient's continued commitment to the foundation's charitable purpose and not merely to charitable purposes in general; ${ }^{32}$ (iii) how to balance the control mechanisms required by federal tax law against the risk of fiduciary duties under the applicable state entity law; and (iv) the potential of the investment producing private benefits that are not merely incidental to the foundation's charitable purposes. ${ }^{33}$

In short, a prudent PRI analysis cannot be quick, easy, label-driven, or "off the rack."

${ }^{32}$ This concern can also be addressed by providing that recipient will promptly return the PRI (i.e., buy out the private foundation's ownership interest in the recipient) if the recipient deviates from the agreed-upon, foundation-specific charitable purpose.

33 Treas. Reg. § 53.4944-3(a)(3)(i) (“Once it has been determined that an investment is "program-related” it shall not cease to qualify as a "program-related investment" provided that changes, if any, in the form or terms of the investment are made primarily for exempt purposes and not for any significant purpose involving the production of income or the appreciation of property. A change made in the form or terms of a program-related investment for the prudent protection of the foundation's investment shall not ordinarily cause the investment to cease to qualify as program-related. Under certain conditions, a program-related investment may cease to be program-related because of a critical change in circumstances, as, for example, where it is serving an illegal purpose or the private purpose of the foundation or its managers.”) (emphasis added). 


\section{E. PRIs and L3Cs}

The L3C structure does nothing to resolve the several serious issues pertaining to PRIs. Even assuming that L3C status were to guarantee that that each L3C would forever keep profit-making in the background, ${ }^{34}$ a private foundation contemplating a PRI must focus on its charitable purpose in particular and not benevolence in general. Moreover, L3C status does nothing to address the "expenditure responsibility" issue. With an L3C - just like an ordinary LLC - the operating agreement must be tailored to fit the state law entity into the federal tax law requirements.

Likewise, L3C status does nothing to address the state law fiduciary duty questions and nothing to eliminate the specter of private benefit.

As is often the situation with L3Cs, with regard to PRIs, L3Cs promise what they cannot deliver - simple solutions to inevitably complex problems.

\section{F. PRIs, L3Cs, and Tranched Investment}

Tranched investment further complicates the PRI-L3C connection. As discussed above, tranched investment carries substantial risks of private benefit regardless of PRI status. In addition, "top tranche" investors will naturally wish assurance that the L3C will keep their profit-making interests in mind. As a result, establishing "expenditure responsibility" for the private foundation will be more complicated to devise and more difficult to achieve. For the related reasons the potential for fiduciary duty conflicts will increase (because if the L3C encounters financial difficulties the top tranche investors and the foundation will likely be pulling in opposite directions).

Advocates of L3Cs often promote L3Cs as a break-through device that opens a streamlined channel from charitable assets to socially beneficial commercial ventures. To the contrary, the PRI-L3C connection inevitably requires painstaking analysis and planning, which must take into account sometimes contradictory legal requirements and potentially disastrous risk. $^{35}$

${ }^{34}$ As explained above, L3C status does not guarantee this result. Nothing prevents those who control an L3C from deciding to abandon L3C status and the limitations that go with it. Also as explained above, a properly crafted operating agreement can provide for this problem, but: (i) such provisions require careful thought and drafting - i.e., they complicate matters; and (ii) are no simpler in an L3C than in an ordinary LLC.

${ }^{35}$ As discussed below, the same complexity and risk attend a PRI in any for-profit enterprise. But such PRIs have been aggressively promoted only in connection with L3Cs. 


\section{Federal Tax Requirements and the L3C - Summary}

In to regard the myriad requirements of federal tax law, the L3C has no significant advantage whatsoever over the ordinary $L L C{ }^{36}$ By itself, L3C legislation is entirely inadequate to satisfy the requirements of tax law. State law cannot control federal tax law, and the L3C structure cannot streamline, simplify, or "green light" the PRI process.

Tranched investing is extremely complex for a private foundation; a simplistic approach to private benefit will put a foundation's tax exempt status in jeopardy. In addition, tranched investing substantial complicated the already complicated analysis and planning necessary to qualify a private foundation as a PRI.

In sum, from the perspective of federal tax law, the L3C is at best a distraction and more likely a simplistic trap for the unwary.

\section{Defects in the L3C Legislation}

\section{A. The Misleading Implications of L3C Legislation}

\section{In General}

When private foundations put charitable assets in the hands of for-profit entities, federal tax law is acutely, deeply, and inescapably involved. The prohibition against private benefit is long-standing and fundamental public policy of the United States, and there is no reason to expect Congress to overturn that policy. The PRI focus on the private foundation's purpose is similarly fundamental; to make recipient organizations generically qualified would turn the PRI concept "on its head."

State law cannot change the federal tax law, and enacting L3C legislation implicitly but inevitably promises benefits in an area of law over which the state has no control. That promise is the special evil of L3C legislation. Statutes perform a signaling function. They not only regulate; by their terms they suggest what behavior is acceptable. ${ }^{37}$

\footnotetext{
${ }^{36}$ One of the country's foremost experts on PRIs has stated: "I've structured, prepared documents for and closed over 250 PRIs (over \$350 million total) of all forms, and never felt the need for an L3C.” (email, 7/14/11, from David S. Chernoff, Esq.)

${ }^{37}$ James J. Fishman, “Improving Charitable Accountability,” 62 MD. L. REV. 218, 248 (2003) (“the law occupies a signaling function of appropriate behavior"); Karen Gross, Kathryn R. Heidt, Lois R. Lupica, “Legislative Messaging and Bankruptcy Law,” 67 U. PITT. L. REV. 497, 499 (2006) (noting that "legislation performs a signaling function"); Alan Scott Rau, "Contracting Out of the Arbitration Act,” 8 AM. REV. INT'L ARB. 225, 260, n. 147 (1997) (stating that “[a] particular statutory standard may have the signaling function of suggesting a standard that is common and socially approved"); Mark A. Drumbl, "Rights, Culture, and Crime: The Role of Rule of Law for the Women of Afghanistan," 42 COLUM. J. TRANSNAT'L L. 349, 362 (2004) (“[L]aw sends a message, and expressive theories of law tell us that this signaling function is critical to the development of social norms.”);
} 
Especially in light of the claims of L3C advocates, statutory recognition of L3Cs suggests that an L3C is somehow a safer, easier, or otherwise superior type of recipient for a PRI. After all, why would the legislature create a specialized type of entity unless that entity type provided special benefits?

More particularly, L3C legislation "hardwires” into a state statute restrictions that are intended to resonate with federal requirements for PRIs; the claimed compatibility between L3Cs and PRIs has been central to the advocacy for L3C legislation. The obvious implication is that L3C legislation facilitates compliance with PRI requirements. Why would the legislature enact the L3C restrictions if those restrictions did not make compliance easier and simpler? Thus, enacting L3C legislation signals that the L3C can increase and simplify access to PRIs through compliance with state rather than federal law.

This implication is incorrect and misleading. As noted above, in determining whether an investment qualifies as a PRI it is essential to ask whether the investment "significantly furthers the accomplishment of the private foundation's exempt activities and if the investment would not have been made but for such relationship between the investment and the accomplishment of the foundation's exempt activities." 38 Thus, the PRI analysis must always focus on the specific "exempt activities" of the foundation, which means that the private foundation must analyze each potential investment in terms of its suitability to the foundation's mission.

The PRI analysis must also consider carefully the governance structure of a potential PRI recipient, because a PRI investment always involves "expenditure responsibility." The recipient's structure must therefore accord the private foundation sufficient control or exit rights (or a combination) to insure that foundation funds remain committed to acceptable purposes. Devising such controls and exit rights is no simple matter, because the overall structure must also be acceptable to the profit-seeking investors and, moreover, protect the foundation from liability that might arise if the foundation were to exercise too much control over the recipient organization and trigger breach of fiduciary claims.

A state-sponsored label for potential PRI recipients - L3C - suggests that PRI analysis is not only recipient-focused ("a PRI is safe with us because we're an L3C") and but also generic ("because we're an L3C, we're suitable for PRIs generally”). The L3C label also suggests that the L3C structure "as is" resolves the very complex governance and financial issues inherent in any PRI. The result is dangerous for private foundations, especially those that cannot afford expert legal advice.

\section{L3Cs and Tranched Investment}

The "signaling error" is even more egregious with regard to the tranched investment structured promoted by L3C advocates. Although in theory any LLC could attempt to use a PRI for that type of tranched investing, in practice the danger is far greater under L3C legislation. Since their first appearance, L3Cs have been associated with the potential of

\footnotetext{
${ }^{38}$ Treas. Reg. § 53.4944-3(a)(2)(i).
} 
tranched investing. Given that history, a state's enactment of L3C legislation suggests that the state has recognized the L3C mechanism as safe and appropriate not only for PRIs in general but also for tranched investment in particular. From the perspective of federal tax law, quite the opposite may be true - much to the harm of private foundations that may rely upon the apparent legislative endorsement.

\section{State Entity Law Not an Appropriate Method to Create a "Brand" to Identify Socially Beneficial Ventures}

From the outset, discussion of L3C legislation has included the notion that the L3C can serve as a "brand" to signal the socially beneficial quality of an enterprise to potential investors and customers. Indeed, once federal tax law is understood, "branding” is all that remains in the pro-L3C argument. But branding - as the term itself suggests - is a function for the private sphere. Branding has never been the function of the law of business organizations, and a low profit limited liability company remains a business organization.

Some L3C proponents have claimed that the L3C label is a proper "brand" because the L3C structure makes social benefit the primary purpose of the entity. As previously noted, without appropriate language in the operating agreement, the L3C legislation cannot prevent an entity from abandoning social benefit through the simple mechanism of dropping the L3C label.

Moreover, even in this context the "brand" is a misleading signal of simplicity. Assuming that an L3C has members who expect some return on their investment, the operating agreement must address how the managers will balance the potentially competing interests. According primacy to social benefit does not by itself adequately answer the balancing question. With the tranched investment arrangement, the problem becomes extreme. You cannot promise investors above-market rate returns and then assume that "primacy" resolves conflicts in every instance. You can state in the operating agreement that in every instance the social benefit trumps the pecuniary interest, but: (i) the statutory language alone does not so provide; and (ii) the L3C will have to be very careful with its representations to the for-profit investors.

More fundamentally, when it is important to brand business organizations regarding issues of social concern, advocates of social justice and well-intentioned businesses find powerful private means to create a brand. Consider, for example, the Sullivan Principles, which established rigorous standards (enforced through public opinion) for companies dealing with apartheid South Africa. ${ }^{39}$ Consider currently the numerous private

${ }^{39}$ http://muweb.marshall.edu/revleonsullivan/indexf.htm, last visited 6/9/11 ("When Leon Sullivan joined the Board of Directors at General Motors in 1971, he used his corporate foothold to oppose apartheid, the government policy of segregation in South Africa. Since the passage of a Declaration of Grand Apartheid in 1948, a number of reformers, including Nelson Mandela, had tried unsuccessfully to end apartheid.

General Motors was the largest employer of blacks in South Africa at that time, and Sullivan decided to use his position on the Board of Directors to apply economic pressure to end the unjust system. The 
organizations that assess the "green" quality of products and services ${ }^{40}$ and the influence on businesses of the Halo Awards, the Gold Standard Certification of the Women in Law Empowerment Forum, and other such devices. ${ }^{41}$ State government is not needed to create branding for private enterprises; it is not the function of the law of business organizations to do so.

\section{The Technical Error in the L3C Legislation}

As noted above, House File No. 2702 incorporates almost verbatim the wording of the federal PRI regulations. In particular, in section 6, the bill provides that: "A significant purpose of a low-profit limited liability company must not include the production of income or the appreciation of property."42 Tranched investing cannot possibly work under this constraint. In the L3C context, foundation funds are used to subsidize "top tranche” investors. These investors seek at least a market rate of return; their investment is premised on the expectation of profit. More generally, when "no significant purpose of the company is the production of income or the appreciation of property," the label "low profit limited liability company" is a misnomer.

result was the Sullivan Principles, which became the blueprint for ending apartheid.”). Congress eventually incorporated the Principles into the Comprehensive Anti-Apartheid Act of 1986, Pub.L. No. 99-440, 100 Stat. 1086 (1986). The Act "required American businesses with more than 25 employees in South Africa to comply with the Sullivan Principles, a code of fair employment practices for companies operating in South Africa.” Board of Trustees of Employees' Retirement System of City of Baltimore v. Mayor and City Council of Baltimore City, 562 A.2d 720, 740 (Md. 1989). When apartheid ended, the requirement was repealed. Pub.L. 103-149, § 4(a)(1), (2), Nov. 23, 1993, 107 Stat. 1503. However, the Sullivan Principles are still at work. http://www.thesullivanfoundation.org/about/about_the_organization , last visited 6/9/11. ("We endeavor to bring the corporate and governmental communities together for the economic benefit of all, and invite businesses and individuals to create partnerships with Africa with our ultimate goal being a peaceful, prosperous, and powerful Africa.”).

40 See e.g. "BMW Picks Up Three Honours at the Environmental Transport Association's Green Car Awards 2010,” http://www.bmwblog.com/tag/environmental-transport-association\%E2\%80\%99sgreen-car-awards-2010/, last visited 6/12/11.

${ }^{41}$ http://www.causemarketingforum.com/site/c.bkLUKcOTLkK4E/b.6381267/k.BEDB/Home.htm; last visited 6/12/11; http://womenlawyerleaders.blogspot.com/, last visited 7/6/11.

${ }^{42}$ Minn. House File No. 2702, § 6, lines 5.20-5.22. 


\section{E. No Need for an L3C Subcategory}

Under Minnesota's existing LLC statute, it is already possible to create a low profit limited liability company. Under Minn. Stat. § 322B.37, a member control agreement has complete authority to determine the LLC's purpose, to allocate governance and financial rights differentially among members, and to protect the agreed structure from inappropriate revisions. ${ }^{43}$ L3C legislation adds nothing, and, as explained above, will cause the Minnesota to send inaccurate signals about the safety and effectiveness of L3Cs.

\footnotetext{
${ }^{43}$ Minn. Stat. § 322B.37 (2010). A member control agreement under Minn.Stat. ch. 322B is equivalent to
} an operating agreement under other state LLC statutes. 